\title{
Nexus between Financial Inclusion, Gender and Agriculture Productivity in Ghana
}

\author{
Blessing Amos Atakli ${ }^{1}$, Wonder Agbenyo ${ }^{2}$ \\ ${ }^{1}$ School of Finance, Zhongnan University of Economics and Law, Wuhan, China \\ ${ }^{2}$ College of Economics, Sichuan Agricultural University, Chengdu, China \\ Email: agbenyowonder@gmail.com, amosatakli@gmail.com
}

How to cite this paper: Atakli, B. A., \& Agbenyo, W. (2020). Nexus between Financial Inclusion, Gender and Agriculture Productivity in Ghana. Theoretical Economics Letters, 10, 545-562.

https://doi.org/10.4236/tel.2020.103035

Received: March 26, 2020

Accepted: June 5, 2020

Published: June 8, 2020

Copyright $\odot 2020$ by author(s) and Scientific Research Publishing Inc. This work is licensed under the Creative Commons Attribution International License (CC BY 4.0).

http://creativecommons.org/licenses/by/4.0/

\begin{abstract}
The concept of infrastructure, education, availability, usage, affordability, inequality, and accessibility of funds remains useful in agricultural productivity. Nonetheless, the most instrumental challenge of rural farmers is the factors mentioned above, which hindered the growth of agricultural productivity over the years in Africa. As a result, this study examines the nexus between gender, financial inclusion, and Agriculture Productivity in Ghana. The study adopted a cross-sectional research design with secondary data sources from the Ghana Living Statistical Survey 7. Data were analyzed using STATA version 15 . The objective of the study was analyzed using the ordinary least square method. The study revealed that financial inclusion has a significant positive relationship with agricultural productivity. Also, factors such as age, farm size, household size, ownership of land have a positive impact on agricultural productivity coupled with the low level of education. Results indicate that farm size, equipment ownership, expenditure on inputs, age, marital status, land ownership, household size, and education level are determinants of agricultural productivity. The paper revealed that male farmers are more financially inclusive than their female counterparts. As a result, the study concluded that there are strong links between gender, financial inclusion, and agricultural productivity. The government and other stakeholders in Ghana need legal and institutional transformations that will help meet the needs and constraints of females, especially in the rural communities, to broaden the scope of financial services hence making them financially inclusive.
\end{abstract}

\section{Keywords}

Financial Inclusion, Agriculture Productivity, Gender, Ghana

\section{Introduction}

Agriculture is a primal economic activity in the African trade and industry sec- 
tor that involves about $55 \%$ of the populace, meanwhile only a minimal percentage, that is, $1 \%$ of the loan instruments and facilities of banks are channeled into the sector of agriculture. Additionally, an approximate adult percentage of $4.7 \%$ of adults in rural areas in developing countries globally have credit from recognized financial establishments. In contrast, only 5.9\% are holders of a bank account, as recorded by Findex data. Agbenyo et al. (2019) argues that developing countries such as Ghana and other African countries are confronted with a series of obstacles such as low output, restricted access to finance, poor roads, high-cost labor, and the absence of adequate risk management techniques and facilities such as agricultural insurance. However, accentuate that agriculture relics as the bedrock of growth to any economy regardless of their level of development.

In Ghana, the proportion of agriculture to GDP is around $40 \%$, and the fragment uses approximately $55 \%$ of the working population. For the rural community, agriculture continues being the primary source of livelihood, contributing significantly to ensuring food security and represent around 50 percent of the nation's export profit. Given this fact, Agbenyo et al. (2019) posit that for a substantial development of the agriculture sector, access to finance, availability, affordability, incorporation of the rural finance into the formal and informal financial system is critical and cannot be undervalued. However, financial inclusion and agricultural productivity are significant issues in Ghana, as admitted in a 2007 report by the Ministry of Food and Agriculture, stating that low agricultural productivity has become a substantial concern in recent times. Scholars including Awumbila and Ardayfio-Schandorf (2008), Aasoglenang et al. (2013), and Hilson \& Garforth (2013) are of the view that low agricultural productivity has compelled most of the rural households to diversify from regular crop farming as a means of sustaining minimum income for survival. Financial inclusion serves as the medium through which financial institutions engage or make available financial services either, affordable, reliable, and accessible to rural farmers that are not included in formal or informal financial services. Financial inclusion serves as the remedy to accessing credit by rural farmers since their incorporation will enable them to acquire some level of knowledge about finance and its usage based on the quality of the financial service provided to them.

Money answerers everything they say. By implication, rural farmers' access to credit and being financially incorporated will enable them to get answers to significant issues they encounter on the farm daily hence increase agriculture productivity in the long run. Thus, available funds for investment ineffective farming techniques geared towards boosting productivity, enhancement of post-harvest practices, improvement of family unit income, empowerment of access to business sectors, and advancement of better risk management practices. Various studies have been conducted to reveal the impact of Agriculture finance on agriculture production in both developed and developing economies. Petrick (2005) posits that credit is viewed as a critical prerequisite for promoting eco- 
nomic growth and intensifying living standards in rural areas and also serves as a means through which rural household's liquidity problem can be amended. Meanwhile, Feder et al. (1990) earlier stated that production systems such as the agriculture sector use of credit are not only essential but helps to determine how much inputs can be utilized.

Gender and financial inclusion are very scared in literature. Similarly, to gender and agricultural productivity, the few studies are also very scanty in conclusion. For instance, Peterman et al. (2010) admitted that numerous factors might lead to agricultural productivity differences between men and women in the developing world. They iron out that, assuming men and women have the same agricultural production function and use the same technique for the same crop, the number of inputs (e.g., fertilizer, seeds, or labor) applied by men and women may differ. They further revealed that the quality of inputs might vary. Thus, the Land quality may differ between men and women, including, but not limited to, soil quality, topography, and proximity to access points such as water sources, roads, and housing Nkedi-Kizza et al. (2002) and Tiruneh et al. (2001). Goldstein and Udry (2008) find substantial differences in profits between plots controlled by men and those controlled by women in Ghana; however, this finding is entirely explained by the duration of the fallow period. Quisumbing (1996) portrayed that lower yields on female-owned packages of cocoa in Ghana. Kinkingninhoun-Mêdagbé et al. (2010) find productivity differences between male and female farmers within a Benin semi-collective rice irrigation scheme. Still, the finding can be attributed to scheme membership and access to land and equipment. Oladeebo and Fajuyigbe (2007) find female rice farmers are more technologically efficient compared to male farmers in Osun State, Nigeria.

Concerning the issues iron out above and forthcoming, there is an urgent need to investigate the relationship between gender, financial inclusion, and agricultural productivity in Ghana. Based on the numerous issues and as follows, a report in 2011 by the stakeholders of agriculture in Ghana indicated that the most instrumental challenge of rural farmers is inadequate access to credit, which has hindered the growth of agricultural productivity for years. Accessibility to credit is a subset of financial inclusion. In simple terms, if financial inclusion can be given the utmost attention, especially among rural farmers, then access to credit would be minimized. In any case, the rural farmers comprising $90 \%$ and are producing almost about $80 \%$ of the sector's output. The few existing studies cited earlier include Crook and Sverrisson (2001), Magri (2002), Thaicharoen et al. (2004), Crook and Hochguertel (2005), Del-Rio and Young (2005), Akudugu et al. (2009). In addition to the above, precise studies in Ghana includes Owusu-Antwi and Antwi (2010), Akudugu (2012), Baffoe et al. (2014) and Dzadze et al. (2012). They are not only empirically inadequate but also not complete enough to conclude on financial inclusion and agricultural productivity since credit is just a subset of financial inclusion. Other scholars also specified that financial inclusion leads to poverty reduction, decrease in the level of in- 
equality and enhanced private investment (Demirguc-Kunt and Klapper, 2012), Beck, Demirguc-Kunt, and Peria (2007), Mbutor and Uba (2013), Selvakumar et al. (2015), Olaniyi (2017), Sakanko et al. (2018) and Satsangi \& Tiwari (2018). Other studies (including Mohan (2006), Agrawal et al. (2008), Cnaan, Moodithaya, and Handy (2012), Sharma and Kukreja (2013), Paramasivan and Ganeshkumar (2013) discovered that financial inclusion has a significant impact on economic growth.

Briefly, the relationship between gender, financial inclusion, and agricultural productivity is scared in literature, especially in developing countries like Ghana. Finally, to assume there is enough research, most of these studies focused on macro indicators and ignoring the heart of the real issue making this study worthy and productive enough as it focuses on micro-level data for its analysis. The desire for this study emanates from the huge gap left in literature. Despite the imperative role that the agriculture sector plays, there is no empirical evidence available on the relationship between gender, financial inclusion, and agriculture productivity, specifically in Ghana. Additionally, connecting gender, financial inclusion, and agriculture productivity could help determine inequality of access and usage of funds from financial institutions to farmers in the rural areas and thereby reducing poverty and increasing productivity.

\section{Literature Review on Gender, Financial Inclusion, and Agricultural Productivity}

Ideally, many studies support the notion that financial inclusion is needed throughout the agricultural value chain to achieve broad-based economic growth, which can raise incomes for low-income households. The relationship between gender, financial inclusion, and agriculture productivity, however, remains an open question. A study conducted by Abu and Haruna (2017) investigated the connections between financial inclusion and agricultural commercialization among farmers in Ghana. In their research, it has been revealed that financial inclusion significantly promotes agricultural marketing. However, the study which used endogenous switching regressions emphasized maize farmers while the current study examines responses from the agricultural sector as a whole. This study speculates that there are more benefits to gain by ensuring farmers have access to a broad range of financial services. The researcher, therefore, stated that financial inclusion is low among maize farmers, but a similar study is yet to be conducted among farmers with different farm produce. The study did not perceive any significant impact of financial inclusion on the traditional mode of farming but rather the commercialized ways.

A study conducted by Agunuwa, Inaya, and Proso (2015) collected information from both primary and secondary sources aimed at investigating the bank's credit and agriculture development from five banks and ten agricultural enterprises in Delta State. The study adopted simple random sampling through the lottery method in selecting its participants who were involved in the survey. Da- 
ta collected for this study used percentages, mean scores, Standard Deviation, and Pearson product-moment correlation to test the respective hypotheses. They discovered that bank credits to agricultural entrepreneurs encourage agricultural growth and productivity. Elaborating on this finding, we can express that the researcher suggested the need for adequate bank credits.

A study conducted by Ogunniyi, Ajao, and Adeleke (2012) on gender comparison in production and productivity of cocoa farmers relied on the primary source of data, where 100 questionnaires were responded to among cocoa farmers in Nigeria Oluji Local Government Area. The study could not investigate how financial inclusion influence agricultural production. More so, other food crops were not captured since the study was limited to cocoa farmers. However, this study was conducted using secondary data from Ghana living a statistical survey (GLSS), where data was collected on over a thousand three hundred participants across Ghana. The study was limited to a particular geographical area, but the current study examined gender differences among farmers nationwide. The earlier study revealed that most cocoa producers are not technically efficient, which implied a lot could be done to increase their productivity. The study discovered that the majority of farmers who engaged in cocoa production are grown-ups as more of the young farmers do not participate much in cocoa production. Low level of education was another factor influencing cocoa production reported by earlier scholars. A thorough investigation of the farmers' efficiency revealed that age, education, and experience were significant in technical inefficiency.

In contrast, the female inefficiency model was significant in the education, experience, and age of the cocoa plant. The technical efficiency showed that much could be done to increase the production capacity of both genders to make them technically efficient. The current study examined beyond cocoa farmers by involving farmers with different food crops such as yam, cocoa yam, maize, cassava, and others into the study; hence it could be more generalized compared to the findings of Ogunniyi, Ajao, and Adeleke (2012).

Similarly, Nyayon (2015) also conducted a study to assess productivity differentials that are often seen in the agricultural sectors of developing countries from the gender perspective. Nyayon's carried out a survey in the Northern part of Ghana concentrated on cotton production with no attention paid to financial inclusion. The study adopted a cross-sectional research design collected data from 200 participants who were involved in the study through the filling of questionnaires. The research portrayed that there was no significant difference in the proportion of males and females concerning the month of the plow as well as the method of fertilizer application. However, there is a gender differential in the use of their labor and family labor on the farms. They came out that there was no significant difference in mean years of farming experience of male and female farmers. By implication, farmers, irrespective of gender, have all acquired the necessary expertise in cotton production that can positively affect the pro- 
duction process and adoption of new technologies. Availability and equality of opportunities to access financial services is the gap this study intends to fill. Fletschner (2008) reports that women with less access to credit produce less than they could do with consequences that are very substantial since the absence of credit can have vital implications on the ability to undertake productive activities.

According to Okurut et al. (2004), credit is an essential instrument for improving the welfare of the poor. They argued it could be achieved directly through consumption by increasing their purchasing power and improving their income sources through financial investment in their human and physical capital to reduce their vulnerability to short-term income. Financial inclusion is one crucial input to agricultural production that must be given considerable attention by every farmer. Access input is the major challenge that women-farmers face and not the propensity to use it. Demirguc-Kunt, Klapper, and Singer (2013) study financial inclusion and legal discrimination among women from developing countries. The results from their probity models and ordinary least squares (OLS) regressions document that individual characteristics such as income, education, employment status, rural residency, age, and gender remain significantly related to the usage of financial services. Our estimate also found that some of the cross-country variation in access to finance by women may be explained by legal discrimination against women and gender norms. They observe that women are less likely to own an account, compared to men, as well as to save and borrow in countries where women face legal restrictions on their ability to work, head a household, choose where to live, and receive an inheritance. Results of Demirguc-Kunt, Klapper, and Singer (2013) also confirm that explaining the variations in the use of financial services between men and women after controlling for other individual and country characteristics was as a result of manifestations of gender norms. In examining an overview of financial inclusion in Africa using descriptive statistics Demirguc-Kunt and Klapper (2012) report that less than a quarter of adults in Africa have an account with a formal financial institution and that many adults in Africa use informal methods to save and borrow. Thus, $23 \%$ of adult Africans have accounts at a legal, financial institution, and about 77\% remained unbanked (do not have a bank account at a formal financial institution).

\section{Model Specification, Data and Estimation Techniques}

The paper investigates the nexus between gender, financial Inclusion, and agriculture productivity in Ghana, by employing the ordinary least squares, multiple regression model. The multiple regression model specified for the impact of financial inclusion on the productivity of agriculture is as follows:

Model 1: Financial Inclusion on Agricultural Productivity model

$Y=f($ OSA, OIA $, A T M, T e B, A C$, Age, Equi, Hsize, Edu, Ctype, LandO, FarmS $)(1)$ 
This model will be transformed into an econometric model as

$$
\begin{aligned}
A p= & \beta_{0}+\beta_{1} \text { OSA }+\beta_{2} \text { OIA }+\beta_{3} \text { ATM }+\beta_{4} \text { TeB }+\beta_{5} A C+\beta_{6} \text { Age } \\
& +\beta_{7} \text { Equi }+\beta_{8} \text { Hhsize }+\beta_{9} \text { Edu }+\beta_{10} \text { Croptype }+\beta_{11} \text { LandO } \\
& +\beta_{12} \text { FarmSize }+\beta_{13} \text { fininc }+\varepsilon_{t}
\end{aligned}
$$

where; $A p$ being the dependent variable represents agriculture productivity and its measured as crop yields $\mathrm{kg}$ per hectare. $O S A$ represents ownership of savings account, $O I A$ is the ownership of investment account, $A T M$ being the proxy for transactions made by a farmer using the ATM, TeB represent transaction made by the use of e-banking, and $A C$ depicts the accessibility to credit by a farmer, Age is the estimated age of the farmers. Equi Represent usage of farm equipment, Hsize signifies household size, Edu denotes the education level of farmers, Ctype is the type of crop that a farmer plant. LandO indicates the ownership of the land of the farmer and FarmSize represent the size of the land used by a farmer in farming. $\varepsilon_{t}$ is the stochastic error term in the model. $\beta_{0}$ is the constant intercept and $\beta_{1}, \beta_{2}, \beta_{3}, \beta_{4}, \cdots, \beta_{n}$ are the parameter elasticity coefficients. Again, to enable the interpretation of the partial elasticities, which addresses the degree of responsiveness of the dependent variable to the respective economic independent variable, it is essential to introduce log into the model. We transformed the model into:

$$
\begin{aligned}
\ln A p= & \beta_{0}+\beta_{1} O S A+\beta_{2} \text { OIA }+\beta_{3} A T M+\beta_{4} T e B+\beta_{5} A C+\beta_{6} \ln \text { Age } \\
& +\beta_{7} \text { Equi }+\beta_{8} \ln \text { Hhsize }+\beta_{9} E d u+\beta_{10} \text { Croptype }+\beta_{11} \text { LandO } \\
& +\beta_{12} \ln \text { FarmSize }+\beta_{13} \text { fininc }+\varepsilon_{t}
\end{aligned}
$$

\section{Model 2: Agricultural Productivity difference among Male and Female}

$$
\begin{aligned}
\ln A p= & \varphi_{0}+\varphi_{1} O S A+\varphi_{2} O I A+\varphi_{3} A T M+\varphi_{4} \text { TeB }+\varphi_{5} A C+\varphi_{6} \text { Age } \\
& +\varphi_{7} \text { Equi }+\varphi_{8} \text { Hsize }+\varphi_{9} \text { Edu }+\varphi_{10} \text { Ctype }+\varphi_{11} \text { Land } O \\
& +\varphi_{12} \text { Farm } S+\varphi_{13} \text { Gend }+\beta_{14} \text { fininc }+\varepsilon_{t}
\end{aligned}
$$

where gend also represents the number of gender measures as a dummy where Female $=0$ and Male $=1$. $\varphi$ is the parameter elasticity coefficients.

\subsection{Theoretical and Apriori Assumptions}

After specifying the models for this study, the variables in consideration in the model are further explained couple with their expected apriori signs as follows:

Age of the farmer: the age of farmers in the study is measured in years. Just as the life cycle syndrome holds, the older one gets the lesser interest will he or she be willing to save. Hence it is expected that the older a farmer, the less likely will he be willing to invest; hence his interest in financial issues will be less, and the inverse is true. This assertion has been affirmed in studies such as (Falola and Essien, 2013), Ellis (2016), Langyintuo and Mulugetta (2005).

Gender. this variable itself is dichotomous. Hence it will be measured as such with a male as 0 and female as 1 . Scholars portrayed that male counterparts are well endowed with resources, therefore, the higher the probability of males, the 
higher likelihood of it influencing the growth of agriculture since Okoffo et al. (2016), Ellis (2016) and Wan et al. (2014).

Household Size: Okoffo et al. (2016) argue that a farmer with a larger household size will be more reluctant to spend his/her income on other things rather than using it in his household. However, Wairimu et al. (2016) in relating to Abdulai et al. (2008) revealed that households with large size have the numbers in terms of labor and therefore need more food hence will be willing to invest in agriculture. Concerning the inconsistency, this study hypothesizes household size to have both positive and negative influences on the growth of agriculture.

Household Head: This variable refers to the head of the entire household. The household head is a dummy variable that takes 0 if the farmer is a man and 1 if not. The responsibility of a male household head according to the socio-cultural construct of the area is primarily farm work. However, women's household heads have the additional task of housekeeping that may hinder them from giving their farms the full attention it deserves. It is assumed that male household heads will contribute more to their productivity levels than their female counterparts.

Ownership of land: this variable determines the amount of land owned by the household. It also determines if the farmer can buy or sell land in recent times. Ownership of land is influenced by the ability of the farmer to have landed on his own. It determines whether a particular land is permanently owned or owned for a specified period. It is expected that farmers who have a larger portion of land stand to produce more agricultural goods since agricultural productivity is increased with the available land space.

Level of Education: education is a continues variable and expected to have a positive influence on a farmer who is highly educated since he will know about finance and will be able to acquire and understand the information presented on finance (Okoffo et al. (2016), Falola and Essien (2013), Enete and Igbokwe (2009)).

Agricultural Inputs. these variables involve capital, labor, and other resource used in agricultural production processes. Farmers with high inputs are likely to earn the highest return. The input determines the type of fertilizer applied as well as the usage of a tractor and other equipment.

Agricultural Productivity: this variable will be considered as the dependent variable. It will be used as the proxy for productivity in agriculture in the Ghanaian economy. This variable determines an increase in agricultural productivity and market access. Agriculture productivity is seen from the perspective of agricultural commercialization as well as small scale rural infrastructure development and management. Agricultural commercialization aims to strengthen the capacity of farmers and their service providers to scale up best practices and to adopt improved technologies in production and processing. Small scale rural infrastructure development and management seek to support the construction, rehabilitation, and improvement to increase productivity and efficiency of 
key-value chains by improving access to markets. Possibility of having larger agriculture productivity depends on the ability of the farmer to use both agriculture commercialization and small-scale rural infrastructure development and management.

\subsection{Data Source}

The study adopted a cross-sectional method and data collected by the Ghana Living Standard Survey in short GLSS. The study takes the recent round which is wave 7 due to its focus on agriculture module. Data collected were analyzed using STATA version 15. The GLSS 7 is suitable for this study based on the topic in question and the authenticity of the survey couple with its current information that it contains.

\section{Empirical Results and Discussions}

\subsection{Descriptive Statistics}

Table 1 and Table 2 present the summary statistics for the variable used in the study. Gender and financial inclusion distribution of farmers are captured in Table 1, while Table 2 captures the summary statistics of the other variables.

In terms of financial inclusion, 2438 of the sample representing 17.8 percent of farmers are financially included. Thus, they have access to quality financial services, and they are putting them into use. Eleven thousand two hundred fifty-eight (11258) of the farmers, representing 82.2 percent of the sample, are financially excluded; thus, they either lack access to financial (See Table 1). It is observed from Table 1 that the sample is evenly distributed in terms of gender. Fifty (50) percent of farmers are male, and 50 percent are females. More males thus 1452 representing 10.6 percent of the sample is financially included compared to 986 of females representing 7.2 percent of farmers.

Table 2 captures the summary statistics of the variables employed in the study. As observed from the table (Table 2) that the average agriculture productivity is 5.18 percent with minimum and maximum values of -3.41 and 10.48 percent, respectively. Whereas 75.7 percent of farmers own lands, less than 20 percent (17 percent) of farmers own the equipment they use on the farm. It implies that most farmers either borrow or rent the equipment they use on their farms. On averages, farmers spend 4.48 percent on inputs with an average farm size is 12.18 arches.

The data also shows that, on average, a household is made up of 4 members. About 42 percent of farmers are married with an average age of 30 years. The sample is, however, evenly distributed, with 50 percent of farmers being male and 50 percent female. In terms of educational level, the results indicate that the majority of farmers (62.9 percent) have primary education, and 26.8 percent have secondary education as their highest level of education. 8.8 percent of farmers have tertiary education as their highest level of education, while 1.5 percent 
of the farmers have no education (see Table 2). As emphasized in the study of (Nyayon, 2015) who posits that though both genders are much involved in farming, their educational level is not deficient.

\subsection{Determinants of Agricultural Productivity}

The OLS regression results presented in Table 3 also show the effect of other socio-economic characteristics on agricultural productivity. The results indicate that farm size, equipment ownership, expenditure on inputs, age, marital status, land ownership, household size, and education level significantly affect agricultural productivity.

Table 1. Financial inclusion by gender.

\begin{tabular}{ccccc}
\hline Sex of & Fin Incl & No Fin Incl & Total & \\
\cline { 2 - 5 } HH Head & Count & Count & Count & $\%$ \\
\hline Male & 1452 & 5419 & 6871 & 50.2 \\
Female & 986 & 5839 & 6825 & 49.8 \\
Total & 2438 & 11,258 & 13,696 & 100
\end{tabular}

Source: Author's Estimations from GLSS 7 data.

Table 2. Summary statistics.

\begin{tabular}{|c|c|c|c|}
\hline Variables & Obs & Mean & Std. Dev. \\
\hline Agriculture Productivity & 13,696 & 5.1823 & 1.569 \\
\hline Financial Inclusion & 13,696 & 0.1776 & 0.1320 \\
\hline Ownership of Land & 13,696 & 0.7565 & 0.4292 \\
\hline Ownership of Equipment & 13,696 & 0.1726 & 0.3779 \\
\hline Farm Size & 13,696 & 12.180 & 8.5945 \\
\hline Expenses on inputs & 13,696 & 4.4875 & 1.4487 \\
\hline Household Head & 13,696 & 1.1155 & 0.3196 \\
\hline Household size & 13,696 & 4.2025 & 2.8691 \\
\hline Gender (Male) & 13,696 & 0.5017 & 0.4999 \\
\hline Age & 13,696 & 29.623 & 8.4022 \\
\hline Marital Status & 13,696 & 0.4198 & 0.4935 \\
\hline \multicolumn{4}{|l|}{ Educational level } \\
\hline Tertiary & 13,696 & 0.0880 & 0.2834 \\
\hline Secondary & 13,696 & 0.2676 & 0.4427 \\
\hline Primary & 13,696 & 0.6289 & 0.4831 \\
\hline
\end{tabular}

Source: Author's Estimations from GLSS 7 data. 
Table 3. Financial inclusion and agricultural productivity.

\begin{tabular}{|c|c|c|c|}
\hline \multicolumn{4}{|c|}{ Dependent Variable: Agriculture Productivity } \\
\hline Independent Variables & Coef. & Std. Err & $P$-Value \\
\hline Financial Inclusion & $0.023^{*}$ & $(0.111)$ & 0.039 \\
\hline Ownership of Land & $-0.172^{\star *}$ & $(0.033)$ & 0.009 \\
\hline Ownership of Equipment & $0.533^{* *}$ & $(0.034)$ & 0.008 \\
\hline Farm Size & $0.004^{* * *}$ & $(0.000)$ & 0.000 \\
\hline Expenses on inputs & $0.242^{\star * *}$ & $(0.009)$ & 0.000 \\
\hline Household Head & -0.144 & $(0.043)$ & 0.101 \\
\hline Household size & $-0.060^{\star *}$ & $(0.460)$ & 0.000 \\
\hline Gender (Male) & $0.169^{* * *}$ & $(0.027)$ & 0.000 \\
\hline Age & $0.006^{* *}$ & $(0.000)$ & 0.006 \\
\hline Marital Status & $0.008^{* * *}$ & $(0.031)$ & 0.000 \\
\hline \multicolumn{4}{|l|}{ Educational Level } \\
\hline Tertiary & $-0.804^{\star * *}$ & $(0.139)$ & 0.000 \\
\hline Secondary & -0.113 & $(0.124)$ & 0.365 \\
\hline Primary & $-0.546^{\star \star \star}$ & $(0.121)$ & 0.000 \\
\hline Constant & $4.898^{* * *}$ & $(0.143)$ & 0.000 \\
\hline Observations & 13,696 & & \\
\hline F Statistics & 13 & & \\
\hline Prob $>$ F & & & 0.000 \\
\hline R-squared & 24.2 & & \\
\hline
\end{tabular}

Standard errors in parentheses ${ }^{* *} p<0.01,{ }^{* *} p<0.05,{ }^{*} p<0.1$. Source: Author's Computation from GLSS7.

The coefficient of input expenses is positive and statistically significant at $1 \%$ level. All things being equal, the more farmers spend on inputs, the higher the output obtained. It implies that when farmers apply appropriate farm inputs, it will lead to an increase in farm productivity by 24.2 percent. In a similar study carried out by Lopez et al. (2017), they made use of the propensity score matching method. They discovered that there is no statistical difference between the average expenditures of beneficiaries with agricultural machinery and equipment per hectare. They, however, accentuate that agricultural input donations had a significant effect on the total value of agricultural production in Paragua for the period of 2011-2012 agricultural cycle, which agrees with the finding of this study.

The study discovered that ownership of farm equipment positively influences agricultural productivity in Ghana. The result is significant at the 5 percent level. This implies that farmers who own farm equipment stand the chance of increasing their productivity by 53.3 percent. The probable reason is that these 
farmers will not have to spend so much time moving from one community to the other in a search for one equipment or the other to finish up a task on the farm. Also, in instances where the resources to rent this equipment are not available, it turns to delay work on the farm, which eventually leads to low productivity. Peprah et al. (2019) seeking answers to whether financial inclusion does matter in improving crop yield among smallholder farmers in their study admit to the fact that ownership of agricultural equipment is a determinant of financial inclusion in improving crop yield among smallholder farmers in Ghana. This present study is concordant with the findings of Peprah et al. (2019).

Farm size, marital status, and Age of a farmer positively influence agricultural productivity. The results are significant at the 1 level percent for both farm size and marital status and 5 percent level for the age of the farmer. The result indicates that the larger the farm sizes, the higher the productivity. Farmers who are married stand the chance of increasing their productivity by 0.8 percent. Reasons being that farmer who is married may obtain help from their spouse, which turns to improve their productivity. We observed from Table 3 that as age increases productivity increases. The findings are in line with Peprah et al. (2019).

Land ownership negatively influences agricultural productivity. The result in Table 3 is significant at 5 percent and indicates that farmers that own land have lower productivity than those that do not own land. This finding implies that farmers that do not own land work hard to pay off owners of the lands on which they farm and also get some output for their consumption and sale. Whiles farmers who own land do not need to settle landowners. Hence, they only work for their use and sales. It could account for the negative relationship between land ownership and agricultural productivity.

Household size had a negative and significant effect on agriculture productivity. The result in Table 3 is significant at 1 percent and indicates that as household size increases, there is a 6 percent decrease in agricultural productivity. This finding implies that the higher the household size, the more expenses the farmer are likely to incur, which tends to lower the finances of a farmer in acquiring proper farm equipment or farm inputs that can help enhance productivity. This result contradicts the findings of Nyayon (2015) who found in Ghana that household size increases land productivity of cotton farmers.

The educational levels of a farmer also significantly influence agricultural productivity. Results from Table 3 indicate that both tertiary and primary education significantly affects agricultural productivity compared to farmers with no education. The result implies that the productivity of farmers with tertiary and primary education turns to have low agricultural productivity compared to farmers with no education. The result is not obvious since, in Africa, majority of the people perceive farming to be for the non-educated. In contrast, the acclaimed educated people turn to focus more on the white color job. Hence, the educated are likely to have low productivity than those with no education. The results, however, oppose the findings of Peprah et al. (2019) who found that the 
educated farmer positively impacts crop yield in Ghana.

\subsection{Effect of Financial Inclusion on Agriculture Productivity}

Table 3 present the effect of financial inclusion on agricultural productivity. The results indicated that financial inclusion (thus having access to quality commercial service and putting them into use) increase agricultural productivity by 2.3 percent. This result implies that farmers who are financially included had a chance of increasing their productivity by 2.3 percent. Access to financial services by rural farmers improves their consumption and social demands such as health, education, food, and shelter. By implication, availability of financial services such as loans, savings, deposits, and insurance to farmers will promote agricultural productivity in Ghana. The result is statistically significant at the 10 percent level. This is consistent with Udoka et al. (2016), who conducted a study on the effect of commercial banks' credit on agricultural output in Nigeria. The authors found a positive and significant relationship between commercial banks' lending to the agricultural sector and agricultural production in Nigeria. Again, the result is consistent with the findings of Das et al. (2009), Magri (2002), Owusu-Antwi and Antwi (2010), Akudugu et al. (2009), and Dzadze et al. (2012) who found a positive relationship between access to credit and agricultural productivity. The probable reason for the positive effect of financial inclusion on agricultural productivity is that access to credit will mean that farmers can have enough funds to purchase the input that is required for production. This will then improve farming activities and eventually lead to higher agricultural productivity. However, this result is inconsistent with the finding of Timmer (2009) who observed that there is no significant relationship between financial inclusion and productivity.

\subsection{Gender Differences in Agricultural Productivity}

Table 3 further portrays the effect of gender on agricultural productivity. It is observed that gender has a significant impact on agricultural productivity. Thus, male farmers have higher productivity than their female counterparts. From Table 2 , the richness of male farmers increased by 16.9 percent compared to their female counterparts. This result indicates that female farmers in Ghana have low productivity compared to their male counterparts, and the effect is significant at 1 percent level. The probable reason for this finding is that women are both time burden and time-poor. Thus, they allocate their fixed time between their farm activities and domestic activities. This then leaves them with less time to embark on-farm activities, thereby contributing to their low agricultural productivity (Bradshaw et al., 2013). The result is not surprising as the fallacy of women is to perform house chores.

The result of this study is consistent with the findings of Nyayon (2015) who examined gender differences in cotton production in the Northern Region of Ghana. The author found that there is a significant difference in cotton produc- 
tion between male and female farmers of the Northern Region of Ghana. Specifically, the author found that all things held constant; there is a 71.06 percent difference in cotton production between male and female cotton farmers. Again, this result agrees with the findings of Ogunniyi et al. (2012) in Nigeria. They found a 52.77 percent production difference among male and female farmers in Nigeria.

The result from this study, however, contradicts findings from studies that found that female farmers are more productive (Oladeebo \& Fajuyigbe, 2007) and those that found no significant difference between male and female farmers (Sakala \& Benson, 2002). Specifically, Sakala and Benson (2002) found no crop yield differences by gender of a farmer in Malawi after controlling for socioeconomic and input differences. Whiles Oladeebo and Fajuyigbe (2007) found that female rice farmers are more technologically efficient compared to male farmers in Nigeria, which turn to increase their productivity compared to their male counterparts.

\section{Conclusion and Policy Recommendations}

This paper investigates the nexus between financial inclusion, gender and agricultural productivity to mitigate inequality of access and usage of financial services to farmers in the rural areas and enhance agricultural productivity. Most of the studies reviewed are also based on data with relatively small sample sizes, which limits the choice of methods. This paper contributes significantly to literature by using a sample size of 13,696 . It was discovered that majority of the farmers who own land do not have adequate equipment to explore the land. It has deprived most farmers of farming on a large scale. Farmers instead borrow or rent this equipment to work on their lands. The research showed that financial inclusion had a significant positive relationship on agricultural productivity. By implication, an increase in access to financial services leads to a rise in farm productivity. As argued by Agbenyo et al. (2019) access to financial services such as low lending interest rates would manipulate the cost of borrowing, savings, and purchasing of farm inputs for the expansion of agriculture production hence improving agriculture productivity. The paper also observed that gender had a significant effect on agricultural productivity as more males were believed to achieve higher productivity than their female counterparts. We conjecture that females in African narrative have extra domestic activities especially in the rural areas as compared to their male counterparts hence managing domestic activities coupled with farming becomes complicated and could affect their productivity. In investigating determinants of agricultural productivity, it was observed that the size of the farm and the household, equipment ownership, expenditure on inputs, age, marital status, land ownership, and educational level positively and significantly affect agricultural productivity. To bridge the gap in financial services in Ghana, the government and other stakeholders in Ghana need to transform its financial institutions. This will help meet the needs and constraints 
of females, especially in the rural communities to broaden the scope of financial services hence making them financially literate and inclusive. Evidence from the results indicates that enhancing female access to land ownership or other agricultural resources necessitates the enforcement of laws to pledge equal rights to all.

Future studies should study other determinants of financial inclusion (quality and infrastructure) on agricultural productivity to make the concept of financial inclusion and agricultural productivity intensive and robust since this study was limited to accessibility and usage of financial inclusion.

\section{Acknowledgements}

We thank the Editor and the referee for their comments.

\section{Conflicts of Interest}

The authors declare no conflicts of interest regarding the publication of this paper.

\section{References}

Aasoglenang, A. T., Bonye, S. Z., \& Owusu-Sekyere, E. (2013). Rural Livelihoods Diversity: Coping Strategies in WA West District in Northern Ghana. European Scientific Journal, 9, 139-156.

Abdulai, J. D., Ould-Khaoua, M., Mackenzie, L. M., \& Mohammed, A. (2008). Neighbour Coverage: A Dynamic Probabilistic Route Discovery for Mobile Ad Hoc Networks. In 2008 International Symposium on Performance Evaluation of Computer and Telecommunication Systems (pp. 165-172).

Abu, B. M., \& Haruna, I. (2017). Financial Inclusion and Agricultural Commercialization in Ghana: An Empirical Investigation. Agricultural Finance Review, 77, 524-544. https://doi.org/10.1108/AFR-02-2017-0007

Agbenyo, W., Jiang, Y., \& Antony, S. (2019). Cointegration Analysis of Agricultural Growth and Financial Inclusion in Ghana. Theoretical Economics Letters, 9, 895-911. https://doi.org/10.4236/tel.2019.94058

Agrawal, N., Prabhakaran, V., Wobber, T., Davis, J. D., Manasse, M. S., \& Panigrahy, R. (2008). Design Tradeoffs for SSD Performance. In USENIX Annual Technical Conference (Vol. 57).

Agunuwa, E. V., Inaya, L., \& Proso, T. (2015). Impact of Commercial Banks' Credit on Agricultural Productivity in Nigeria (Time Series Analysis 1980-2013). International Journal of Academic Research in Business and Social Sciences, 5, 337-350. https://doi.org/10.6007/IJARBSS/v5-i11/1921

Akudugu, J. A. (2012). Accountability in Local Government Revenue Management: Who Does What. Information and Knowledge Management, 2, 22-32.

Akudugu, M. A., Egyir, I. S., \& Mensah-Bonsu, A. (2009). Women Farmers' Access to Credit from Rural Banks in Ghana. Agricultural Finance Review, 69, 284-299. https://doi.org/10.1108/00021460911002671

Awumbila, M., \& Ardayfio-Schandorf, E. (2008). Gendered Poverty, Migration, and Livelihood Strategies of Female Porters in Accra, Ghana. Norsk Geografisk Tidsskrift- 
Norwegian Journal of Geography, 62, 171-179. https://doi.org/10.1080/00291950802335772

Baffoe, G., Matsuda, H., Nagao, M., \& Akiyama, T. (2014). The Dynamics of Rural Credit and Its Impacts on Agricultural Productivity: An Empirical Study in Rural Ghana. OIDA International Journal of Sustainable Development, 7, 19-34.

Beck, T., Demirguc-Kunt, A., \& Peria, M. S. M. (2007). Reaching Out: Access to and Use of Banking Services across Countries. Journal of Financial Economics, 85, 234-266. https://doi.org/10.1016/j.jfineco.2006.07.002

Bradshaw, C. R., Groll, E. A., \& Garimella, S. V. (2013). Linear Compressors for Electronics Cooling: Energy Recovery and Its Benefits. International Journal of Refrigeration, 36, 2007-2013. https://doi.org/10.1016/j.ijrefrig.2013.02.002

Cnaan, R. A., Moodithaya, M. S., \& Handy, F. (2012). Financial Inclusion: Lessons from Rural South India. Journal of Social Policy, 41, 183-205. https://doi.org/10.1017/S0047279411000377

Crook, J., \& Hochguertel, S. (2005). Household Debt and Credit Constraints: Evidence from OECD Countries (Working Paper Series No. 05/02). Edinburgh: University of Edinburgh, Credit Research Center.

Crook, R. C., \& Sverrisson, A. S. (2001). Decentralization and Poverty Alleviation in Developing Countries: A Comparative Analysis or, Is West Bengal Unique?

Das, A., Senapati, M., \& John, J. (2009). Impact of Agricultural Credit on Agriculture Production: An Empirical Analysis in India. Reserve Bank of India Occasional Papers, 30, 75-107.

Del-Rio, A., \& Young, G. (2005). The Impact of Unsecured Debt on Financial Distress among British Households. https://doi.org/10.2139/ssrn.824147

Demirguc-Kunt, A., \& Klapper, L. (2012). Measuring Financial Inclusion: The Global Findex Database. Washington DC: The World Bank. https://doi.org/10.1596/1813-9450-6025

Demirguc-Kunt, A., Klapper, L., \& Singer, D. (2013). Financial Inclusion and Legal Discrimination against Women: Evidence from Developing Countries. Washington DC: The World Bank. https://doi.org/10.1596/1813-9450-6416

Dzadze, P., Aidoo, R., \& Nurah, G. K. (2012). Factors Determining Access to Formal Credit in Ghana: A Case Study of Smallholder Farmers in the Abura-Asebu Kwamankese District of Central Region of Ghana. Journal of Development and Agricultural Economics, 4, 416-423.

Ellis, A. W. (2016). Reading, Writing and Dyslexia (Classic Edition): A Cognitive Analysis. Hove: Psychology Press. https://doi.org/10.4324/9781315669991

Enete, A. A., \& Igbokwe, E. M. (2009). Cassava Market Participation Decisions of Producing Households in Africa. Tropicultura, 27, 129-136.

Falola, T., \& Essien, K. (2013). Pan-Africanism, and the Politics of African Citizenship and Identity. Abingdon-on-Thames: Routledge. https://doi.org/10.4324/9780203725030

Feder, J. L., Chilcote, C. A., \& Bush, G. L. (1990). Regional, Local, and Microgeographic Allele Frequency Variation between Apple and Hawthorn Populations of Rhagoletis pomonella in Western Michigan. Evolution, 44, 595-608. https://doi.org/10.1111/j.1558-5646.1990.tb05940.x

Fletschner, D. (2008). Women's Access to Credit: Does It Matter for Household Efficiency? American Journal of Agricultural Economics, 90, 669-683. https://doi.org/10.1111/j.1467-8276.2008.01143.x 
Goldstein, M., \& Udry, C. (2008). The Profits of Power: Land Rights and Agricultural Investment in Ghana. Journal of Political Economy, 116, 981-1022. https://doi.org/10.1086/595561

Hilson, G., \& Garforth, C. (2013). "Everyone Now Is Concentrating on the Mining": Drivers and Implications of Rural Economic Transition in the Eastern Region of Ghana. The Journal of Development Studies, 49, 348-364. https://doi.org/10.1080/00220388.2012.713469

Kinkingninhoun-Mêdagbé, F. M., Diagne, A., Simtowe, F., Agboh-Noameshie, A. R., \& Adégbola, P. Y. (2010). Gender Discrimination and Its Impact on Income, Productivity, and Technical Efficiency: Evidence from Benin. Agriculture and Human Values, 27, 57-69. https://doi.org/10.1007/s10460-008-9170-9

Langyintuo, A. S., \& Mekuria, M. (2005). Accounting for Neighborhood Influence in Estimating Factors Determining the Adoption of Improved Agricultural Technologies (No. 378-2016-21410)

Lopez, C. A., Salazar, L., \& De Salvo, C. P. (2017). Agricultural Input Subsidies and Productivity: The Case of Paraguayan Farmers (No. IDB-WP-802). IDB Working Paper Series. https://doi.org/10.18235/0000683

Magri, S. (2002). Italian Households' Debt. Determinants of Demand and Supply (No. 454). Bank of Italy, Economic Research, and International Relations Area.

Mbutor, M. O., \& Uba, I. A. (2013). The Impact of Financial Inclusion on Monetary Policy in Nigeria. Journal of Economics and International Finance, 5, 318-326. https://doi.org/10.5897/JEIF2013.0541

Mohan, R. (2006). Agricultural Credit in India: Status, Issues and Future Agenda. Economic and Political Weekly, 41, 1013-1023.

Nkedi-Kizza, P., Aniku, J., Awuma, K., \& Gladwin, C. H. (2002). Gender and Soil Fertility in Uganda: A Comparison of Soil Fertility Indicators for Women and Men's Agricultural Plots. African Studies Quarterly, 6, 27-43.

Nyayon, M. Y. (2015). Gender and Cotton Productivity in the Northern Region. Doctoral Dissertation, Accra: University of Ghana.

Ogunniyi, L. T., Ajao, O. A., \& Adeleke, O. A. (2012). Gender Comparison in Production and Productivity of Cocoa Farmers in Ile Oluji Local Government Area of Ondo State, Nigeria. Global Journal of Science Frontier Research, 12, 59-64.

Okoffo, E. D., Mensah, M., \& Fosu-Mensah, B. Y. (2016). Pesticides Exposure and the Use of Personal Protective Equipment by Cocoa Farmers in Ghana. Environmental Systems Research, 5, 17. https://doi.org/10.1186/s40068-016-0068-Z

Okurut, N., Schoombee, A., \& Van dar Berg, S. (2004). Credit Demand and Credit Rationing in the Informal Financial Sector in Uganda. South African Journal of Economics, 73, 482-497. https://doi.org/10.1111/j.1813-6982.2005.00033.x

Oladeebo, J. O., \& Fajuyigbe, A. A. (2007). Technical Efficiency of Men and Women Upland Rice Farmers in Osun State, Nigeria. Journal of Human Ecology, 22, 93-100. https://doi.org/10.1080/09709274.2007.11906006

Olaniyi, E. (2017). Back to the Land: The Impact of Financial Inclusion on Agriculture in Nigeria. Iranian Economic Review, 21, 885-903.

Owusu-Antwi, G., \& Antwi, J. (2010). The Analysis of the Rural Credit Market in Ghana. International Business \& Economics Research Journal, 9, 45-56. https://doi.org/10.19030/iber.v9i8.611

Paramasivan, C., \& Ganeshkumar, V. (2013). Overview of Financial Inclusion in India. International Journal of Management and Development Studies, 2, 45-49. 
Peprah, J. A., Kwesi Ofori, I., \& Asomani, A. N. (2019). Financial Development, Remittances and Economic Growth: A Threshold Analysis. Cogent Economics \& Finance, 7, Article ID: 1625107. https://doi.org/10.1080/23322039.2019.1625107

Peterman, A., Behrman, J., Quisumbing, A. R., \& Nkonya, E. (2010). Understanding Complexities Surrounding Gender Differences in Agricultural Productivity in Uganda and Nigeria. Journal of Development Studies, 47, 1482-1509.

https://doi.org/10.1080/00220388.2010.536222

Petrick, J. F. (2005). Segmenting Cruise Passengers with Price Sensitivity. Tourism Management, 26, 753-762. https://doi.org/10.1016/j.tourman.2004.03.015

Quisumbing, A. R. (1996). Male-Female Differences in Agricultural Productivity: Methodological Issues and Empirical Evidence. World Development, 24, 1579-1595. https://doi.org/10.1016/0305-750X(96)00059-9

Sakala, W. D., \& Benson, T. (2002). Gender Analysis of a Nationwide Cropping System Trial Survey in Malawi. African Studies Quarterly, 6, 223-243.

Sakanko, M. A., Audu, A. U., Lawal, M. C., \& Onimisi, A. M. (2018). Analysis of the Impact of Financial Inclusion on Poverty Reduction in Minna Niger State, Nigeria. Abuja Journal of Economics and Allied Field, 8, 80-90.

Satsangi, D. P., \& Tiwari, N. (2018). Experimental Investigation on Combustion, Noise, Vibrations, Performance and Emissions Characteristics of Diesel/n-Butanol Blends Driven Genset Engine. Fuel, 221, 44-60. https://doi.org/10.1016/j.fuel.2018.02.060

Selvakumar, N., Rajaguru, K., Gouda, G. M., \& Barshilia, H. C. (2015). AlMoN Based Spectrally Selective Coating with Improved Thermal Stability for High Temperature Solar Thermal Applications. Solar Energy, 119, 114-121. https://doi.org/10.1016/j.solener.2015.06.047

Sharma, A., \& Kukreja, S. (2013). An Analytical Study: Relevance of Financial Inclusion for Developing Nations. International Journal of Engineering and Science, 2, 15-20.

Thaicharoen, Y., Ariyapruchya, K., \& Chucherd, T. (2004). Rising Thai Household Debt. Assessing Risks and Policy Implications (No. 2004-01). Monetary Policy Group, Bank of Thailand.

Timmer, C. P. (2009). A World without Agriculture: The Structural Transformation in Historical Perspective. Washington DC: Aei Press.

Tiruneh, A., Tesfaye, T., Mwangi, W., \& Verkuijl, H. (2001). Gender Differentials in Agricultural Production and Decision-Making among Smallholders in Ada, Lume, and Gimbichu Woredas of the Central Highlands of Ethiopia.

Udoka, C. A., Mbat, D. O., \& Duke, S. B. (2016). The Effect of Commercial Banks' Credit on Agricultural Production in Nigeria. Journal of Finance and Accounting, 4, 1-10.

Wairimu, J., Ronoh, M., Jaroudi, R., Fotso, P., Kamdoum, V., Matendechere, N., \& Lugoye, J. (2016). A Mathematical Model of Tuberculosis with Drug Resistance Effects. Applied Mathematics, 7, 1303. https://doi.org/10.4236/am.2016.712115

Wan, X., Wang, W., Liu, J., \& Tong, T. (2014). Estimating the Sample Mean and Standard Deviation from the Sample Size, Median, Range and/or Interquartile Range. BMC Medical Research Methodology, 14, 135. https://doi.org/10.1186/1471-2288-14-135 